\title{
外食における米飯のポーションサイズと食器に 関する報告
}

\section{一首都圈の飲食店における穾測調査と外食チェーン店の公開情報 を用いた分析}

\author{
新保 みさ*1, 赤松 利恵*2, 齋木 美果*3, 藤崎香帆里*3 \\ *1長野県立大学健康発達学部食健康学科 ${ }^{* 2}$ 抢茶の水女子大学基幹研究院自然科学系 \\ *3扮茶の水女子大学大学院人間文化創成科学研究科
}

\begin{abstract}
【目的】外食における米飯のポーションサイズを調べることを目的とした。
【方法】東京都，神奈川県，埼玉県（以下，首都圈とする）の飲食店222店舖と外食チェーン店22件を対象とした。首都圈の飲食店では， 定食（米飯とその他2 品以上の料理を含む）の米飯量や米飯の食器の大きさ，その他の料理の重量を測定し，栄養計算を行った。外食 チェーン店では, 各店のホームページから米飯量や米飯のエネルギー量, 米飯の食器に関する情報を抽出した。

【結果】首都圈の飲食店では，米飯の最小值が $142 \mathrm{~g}$, 最大值が $341 \mathrm{~g}$ で, 中央値（25，75パーセンタイル值）は188（163，222） g だった。外食チェーン店では, 最小值が $180 \mathrm{~g}$, 最大值が $250 \mathrm{~g}$ で, 中央值は199（181，228）g だった。首都圈の飲食店と外食チェー ン店ともに, 平皿よりも茶碗で米飯を提供している店が多く, 首都圈の飲食店では, 米飯量と茶碗の直径 $(\rho=0.625, p=0.006)$ に正 の相関があった。

【結論】首都圈の飲食店の米飯量は $160 \mathrm{~g}$ 以上 $200 \mathrm{~g}$ 未満が多く, 外食チェーン店の米飯量は $180 \mathrm{~g}$ 以上 $200 \mathrm{~g}$ 未満が多かった。首 都圈の飲食店の米飯量の中央值は外食チェーン店の米飯量よりも少ないが，店ごとのばらつきが大きく，適正範囲外の店もあった。米 飯は平皿よりも茶碗で提供している店が多く, 首都圏の飲食店では, 茶碗の直径が大きいほざ, 米飯量が多かった。
\end{abstract}

栄養学雑誌, Vol.77 No.4 105-112 (2019)

キーワード：外食, 米飯量, ポーションサイズ, 食器

\section{I . 緒 言}

健康日本21（第二次）では, 国民の健康増進の総合的 な推進に関する基本的な方向の 1 つとして「健康を支 え, 守るための社会環境の整備」をあげている1)。栄養・ 食生活に関しても，望ましい食習慣を推進するために は，環境の整備を促すことが求められている11) 。本の 食環境の 1 つとて外食に焦点を当てると, 1970年代か らファーストフード, ファミリーレストランが誕生し, 外食チェーン店が全国的に広がっている2）。2015年に実 施された国民健康・栄養調査によると，飲食店における 外食を週に 1 回以上している者は, 男性 $40.6 \%$, 女性 $25.1 \%$ で，日常的に外食をしている人は多い3）。このよ うな現状に対して，2018年に日本栄養改善学会等が中心 となり, 外食・中食・事業所給食で「健康な食事（Smart Meal)」を健康的な環境で継続的に提供する店舗や事業 所を認証する制度を始め, 食環境の整備を進めている ${ }^{4)}$ 。

食環境の整備が推進されているものの, 日本では, 外 食の量や内容に関する研究が少ない。アメリカでは, 1
人前の量であるポーションサイズに関する研究が行わ れ，飲食店のシェフ自身は客に対して標準的なポーショ ンサイズを提供していると考えている者が多いが，標準 的なポーションサイズとして認識している量がアメリカ の食事摂取基準による推奨量の 2 〜 倍だったことが示 されている5)。人はポーションサイズが大きくても， 1 人分として提供されると，それが適量だと認識し，食べ 過ぎてしまう6)。実際に, アメリカでは1970年代からの ポーションサイズの増加と並行して体重が増加し, 肥満 が蔓延していることが報告されている7)。一方, 食事を 残すことに対しては各国で様々な考え方がある。例え ば，王らは，中国では食べ残すことが十分に接待された と示す礼儀の 1 つであるため, 飲食店での食べ残しの削

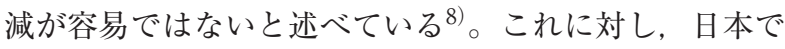
は，食べ物や作り手への感謝の心を表す意味で，残さず 食べることが良いこととされている ${ }^{9)}$ 。したがって，日 本では, ポーションサイズが大きいと認識しても, 残さ ず食べてしまう人が多いことが予測される。

外食の量は, 食べ過ぎによる健康課題に繋がる一方,

連絡先 : 赤松利恵 $\overline{7} 112-8610$ 東京都文京区大塚2-1-1 书茶の水女子大学基幹研究院自然科学系 電話 03-5978-5680 FAX 03-5978-5680 E-mail akamatsu.rie@ocha.ac.jp 
食べ残しによる食品ロスにも繋がる。2015年度の推計に よると, 国内では年間, 事業者から約357万トン10), 家庭 から約289万トン11) の計646万トンの売れ残りや食べ残し などの本来食べられるにも関わらず捨てられている食品 があり，このうちの約133万トンが外食産業から発生して いると推計されている10)。2015年の国連サミットでは, 食料の損失, 廃棄の削減が目標設定され ${ }^{12}$, 外食産業に おいても, 食品口スの削減が必要である。先行研究で は, レストランのポーションサイズを変えることによっ て, 食品ロスが隇ったことが報告されており ${ }^{13)}$, 食べき れないほどのポーションサイズを見直すことで食品ロス 削滅に繋がることが期待できる。

ポーションサイズを見直すためには，ポーションサイ ズに関連する要因を検討する必要がある。先行研究で は, 外食のポーションサイズに強く影響する要因とし て,「料理の見た目」,「コスト」,「客の期待」があげられ ている5)。要因の 1 つである料理の見た目には, 料理が 盛り付けられている皿が影響を与える14 17)。先行研究で は, 同じ量の飯を大きさの異なる 3 つの茶碗で盛り付け たところ，小さな茶碗に盛った時に最も多いと判断した 者が多かった ${ }^{14)}$ 。これは, デルブッフ錯視という人間の 錯覚によって起こると言われており ${ }^{15)}$, 大きな四を使っ た方が, 多く盛り付けてしまったり ${ }^{16)}$, 多く食べてし まったりすることが報告されている17)。さらに, 先行研 究によると, 食器の大きさと摂取量の関連は, 対象者の 体格や国籍によって異なり, 肥満者と比べて普通体重の 者 ${ }^{18)}$, 中国人や韓国人と比べてカナダ人やニュージーラ ンド人の方が摃取量に対する食器の大きさの影響が強 かった ${ }^{19)}$ 。著者らによる日本人を対象とした研究では,

茶碗の大きさと米飯摂取量や満腹感の関連を調べた結 果, 茶碗の大きさと米飯椇取量には関連がみられなかっ たものの, 初めの提供量が多いほど, 搔取量が多く, 満 腹感が高かった ${ }^{20)}$ 。しかしながら, これらの研究は実験 的な環境に扔ける検証であり, 実生活や飲食店に扔ける 食器の大きさと量の関連は調べられていない。

そこで, 本研究の目的は, 外食を対象に, 米飯のポー ションサイズを調べることとした。米飯に着目した理由 は, 日本人の食品群別エネルギー摂取量のうち, 米のエ ネルギー摂取量が総量に占める割合が高く ${ }^{21)}$, 飲食店で 他の食材と分けられて提供されていることが多く, 測定 や比較がしやすいと考えたからである。本研究では, 東 京都, 埼玉県, 神奈川県 (以下, 首都圈とする) に店舗 のある飲食店に扔ける実測調査と, 地域による差がない データとして, 全国的に店舗をもつ外食チェーン店の ホームページに記載されている公開情報の分析を行っ
た。さらに, ポーションサイズに関連する食器に関して も飲食店，外食チェーン店で得られた情報を分析した。

\section{II. 方 法（対象と方法）}

\section{1. 首都圏の飲食店における実測調査}

1 ）手続きと対象店舗

2017年 $1 \sim 10$ 月に, 首都圈の飲食店で定食の重量を料 理ごとに測定し, 茶碗の直径, 高さを測定する調查を 行った。本調查は「飲食店における定食のメニュー作成 要因の質的検討」の研究の一環で行った。対象店舗は, 文京区や調布市の保健所, 研究者の知り合い等の紹介を 通じて募集し，調查を行った店舗からも紹介を求めた。 対象店舖は, カレーや井を除き, 米飯のみの茶碗または 皿があり，その他の料理を 2 品以上含む 1 食分（以下， 定食）を提供していることを条件とした。紹介された店 舖は条件を確認後, 研究者が連絡を入れ, 調査概要を説 明し，協力に同意の意向を示した場合には，店舗へ訪問 した。店舗にて, 研究の目的は適量提供・適量摂取に向 けた食環境整備であることやたずねる内容などの調査の 詳細や調查への参加は自由意思によるもので, 途中で辞 退しても不利益にならないことなどを責任者へ説明した。 同意が得られた場合には同意書に署名をしていただき， 調查を実施した。最終的に25店舗の責任者から協力が得 られた。本研究は米飯量に着目しているため, 25店舗の うち, 米飯以外の主食（パンや湎）も含まれている定食 しかなかった 3 店舗は解析から除いた。調查のために提 供された定食の代金は研究者が負担した。本調査は，お 茶の水女子大学生物医学的研究の倫理特別委員会の承認 を得た（受付番号：2016-25号)。

2 ) 測定方法

各店舗で定食 1 食分の料理ごとの重量を電子秤 (TANITA KD-176) で測定し, 記録した。調查対象の定 食は, 各店舗で最も注文数が多い定食を各店舗の代表值 として, 1 食買い上げ, 調查日に 1 回測定した。店舗に は，普段と同じょうに盛り付けるよう依頼した。食材や 食材の割合を目視で確認し, 不明の場合は責任者へ聞き 取りし, 記録した。全体や料理ごとに写真を撮影し, 定 食のメニュー名，值段についても記録した。店舗の主な 客層に関しても聞き取りし，記録した。これらの記録か ら, 管理栄養士を含む計 2 名の研究者で協議の上, エク セル栄養君 ver. $8^{22}$ を用いて, 定食の栄養計算を行い, エネルギー量を算出した。その際, エクセル栄養君に内 蔵されている料理データで類似するものがあった場合は それをもとにし，なかった場合は食品データから食材料 
を組合せた。野菜は日本食品標準成分表2015年版（七 訂) ${ }^{23)}$ の重量変化率及び調理のためのベーシックデー 夕24)の調理別の重量変化率を参照し, 調理前の野菜量に 変換して栄養計算を行った。ただし，たくあん漬やキム チなどの漬物類や切り干し大根などの乾燥食品は変換を 行わずに，エクセル栄養君の食品ベースから選択した。 茶碗の直径と高さはメジャー（プロマート エコンコン ベックス）を用いて測定し，記録した。

\section{3 ) 解析方法}

対象店舗は, 日本標準産業分類における飲食店の細分 類に基ついて分類した ${ }^{25)}$ 。定食の值段，エネルギー量， 米飯量, 茶碗の直径や高さについて記述統計量を算出し た。米飯量と茶碗の直径や高さは, 正規分布に従わな かったため, Spearmanの順位相関を用いて, 相関係数 を算出した。解析は IBM SPSS Statistics Ver. 24. 0 for Windows（日本 IBM 社）を使用し，有意水準は $5 \%$ （両 側検定）とした。

\section{2. 外食チェーン店の公開情報を用いた調査}

1 ）手続きと対象の外食チェーン店

2018年11月，店舗数の多い外食チェーン店の米飯量と 食器に関する情報をホームページから抽出した。本研究 では, 米飯量に着目し, 全国的に店舗をもつ外食チェー ン店を対象とするため, 一食分の主たる主食として単品 で米飯を提供し，100店舗以上の店舗をもつ外食チェーン 店を対象とした。外食チェーン店の店舗数は, 株式会社 デジタルアドバンテージが公表しているチェーン店一覧 の店舗数のデータを参照した ${ }^{26)}$ 。上記の対象条件に従っ て，データのチェーン店一覧のフードのカテゴリーで,

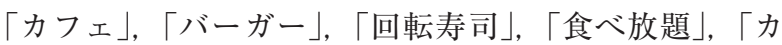
レー」,「お好み／たこ焼き」,「うどん」,「そば」,「べー カリー, 弁当 (寿司) /瑟菜, スイーツ」, 「宅配ピザ」を 除き,「ファミレス」,「ランチ・定食」,「牛井・井も の」,「ラーメン・餃子」, 「しゃぶしゃぶ」,「ふぐ」, 「居 酒屋／やきとり」,「韓国料理」,「牛たん」,「天ぷら」, 「焼肉」,「とんかつ」に分類されている店舗のうち, 店舗 数が100店舗以上の計95件を対象とした。なお，この分類 は株式会社デジタルアドバンテージによる分類及び分類 名である。95件の内訳はファミレス26件, ランチ・定食 4 件, 牛井・井もの 6 件, ラーメン・餃子 17 件, しゃぶ しゃぶ 4 件, 居酒屋 /やきとり 28 件, 天ぷら 1 件, 焼肉 6 件, とんかつ 4 件で, このうち牛井・井ものと天ぷら で 1 件が重複していた。95件の外食チェーン店の店舗数 を合計すると，2018年11月 8 日時点で28, 915店だった ${ }^{26)}$ 。

2 ) 調查方法

2018年11月 8～9 日に, 各外食チェーン店のホーム
ページにアクセスし，メニューや栄養成分表示などから 米飯量と米飯に用いている食器に関する情報を抽出し た。米飯量の小さいサイズや大きいサイズがある場合 は，その米飯量も調べた。地域によってメニュー等が異 なる場合は東京都23区内の店舗の情報を用いた。店舗は 日本標準産業分類に基づいて分類した ${ }^{25)}$ 。日本食品標準 成分表によると, 米飯量 $100 \mathrm{~g}$ が $168 \mathrm{kcal}$ （水稲めし, 精白米, うるち米) であることから ${ }^{23)}$, 米飯のエネル ギー量が記載されている場合は，エネルギー量から計算 し，推定した值を米飯量とした。なお，全ての外食 チェーン店がホームページを開設していた。

\section{III. 結 果}

\section{1. 首都圏の飲食店における実測調査}

1 ）対象の店舗・定食の特徴

最終的な解析対象の店舗は 22 店舗で, 酒場, ビヤホー ル（以下，酒場） 8 店舗, 食堂, レストラン 5 店舗, 日 本料理店 5 店舗, 焼き肉店 2 店舗, その他の専門料理店 2 店舗だった。店舗の所在地は, 東京都が19店舗, 埼玉 県が 2 店舗，神奈川県が 1 店舗だった。

対象の定食は 1 店舗につき, 1 食で, 計 22 食だった。 定食は, 生姜焼き定食, さばの塩焼き定食, 若䳕のから 揚げ定食などだった。值段の中央值（25，75パーセンタ イル值）は905（800，999）円だった。エネルギー量の中 央値は853（717, 1, 147） kcal だった。

2 ）定食の米飯量とエネルギー量

米飯量の少ない順に, 各定食の米飯量, 米飯に用いて いる食器, その食器の直径や高さ, 店の種類, 各店舗の 責任者が答えた主な客層を表 1 に示した。米飯量の最小 值は $142 \mathrm{~g}$, 最大值は $341 \mathrm{~g}$ で, 中央值は 188 (163, 222） $\mathrm{g}$ だった。米飯量の $20 \mathrm{~g}$ ごとの度数分布を図 1 に 示した。米飯量が $160 \mathrm{~g}$ 以上 $180 \mathrm{~g}$ 未満, $180 \mathrm{~g}$ 以上 200 $\mathrm{g}$ 未満が 5 店舗ずつで多かった。

米飯のエネルギー量の中央值は316（273，373） kcal で, 定食全体のエネルギー量における米飯の比率の中央 值は38.5（31.9，50.2）\%だった。

3 ) 米飯に用いている食器と食器の直径や高さと米飯 量との関連

米飯に用いている食器は, 茶碗が19店舗, 平皿が 3 店 舗だった。平皿を用いている 3 店舗は, 看板に「ステー キレストラン」,「ワインのお店」,「肉 BAR」といった記 載のある店舗だった。茶碗の直径の中央值は 11.8 (11.0，12.6） cm だった。茶碗の直径の $1 \mathrm{~cm}$ ごとの度 数分布を図 2 に示した。 $11 \mathrm{~cm}$ 以上 $12 \mathrm{~cm}$ 未満が 6 店舗 
表 1 首都圈の飲食店の定食の米飯量, 食器, 食器の直径・高さ, 店の種類, 主な客層

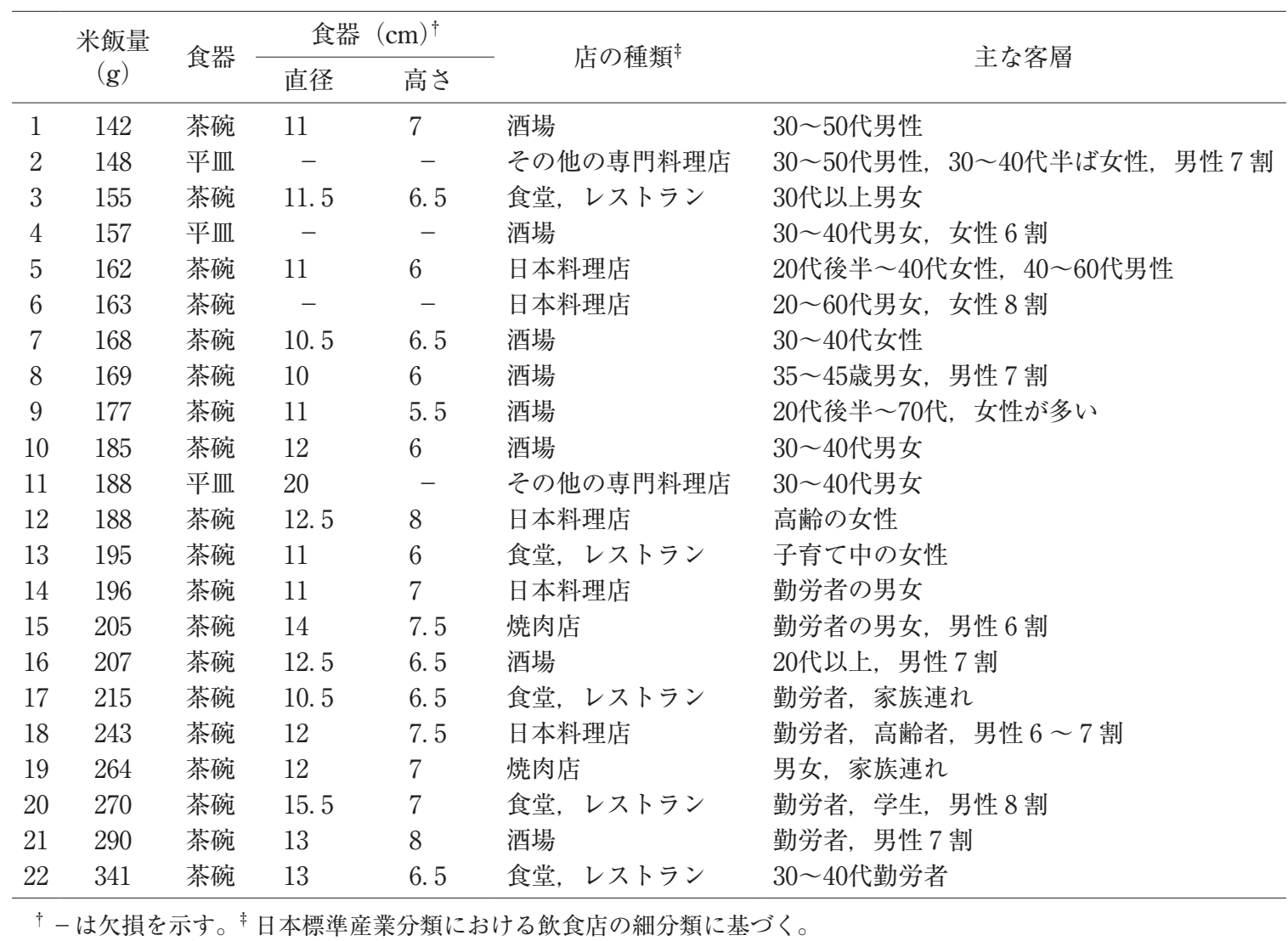

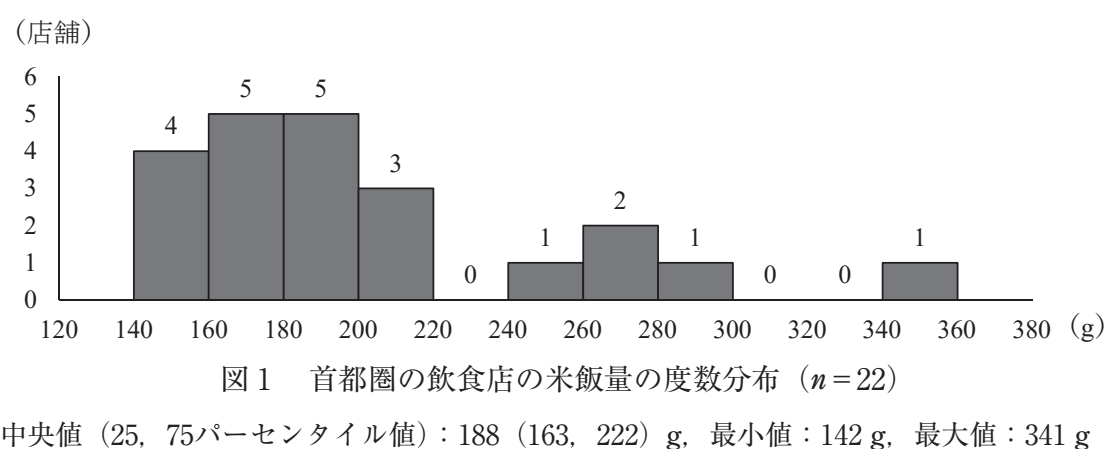

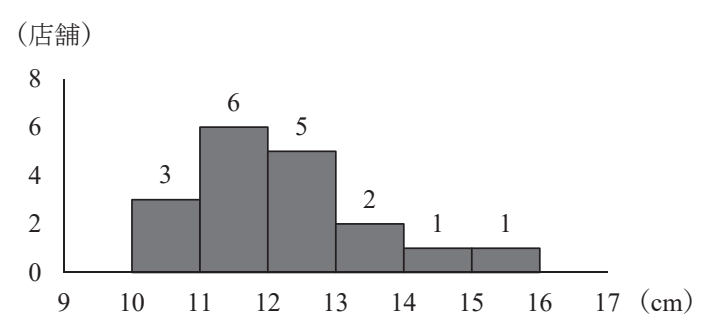

図 2 首都圈の飲食店の茶碗の直径の度数分布 $(n=18)$ 中央值 $(25,75$ パーセンタイル值) : $11.8(11.0,12.6) \mathrm{cm}$, 最小值 : $10 \mathrm{~cm}$, 最大值 : $15.5 \mathrm{~cm}$

で最も多かった。茶碗の高さの中央值は6.5 (6.0,7.1) $\mathrm{cm}$ で, $6 \mathrm{~cm}$ 以上 $7 \mathrm{~cm}$ 未満が 9 店舗で半数程度を占め ていた。平皿の直径のデータがある店舗は 1 店舗で 20 cm だった。

茶碗で提供している店舗の米飯量の中央值は 195 (168，243）g だった。平且で提供している店舗の米飯量 は $148 \mathrm{~g}, 157 \mathrm{~g}, 188 \mathrm{~g}$ だった。茶碗の場合, 米飯量と 茶碗の直径の相関係数は $\rho=0.625(p=0.006)$, 米飯量 と茶碗の高さの相関係数は $\rho=0.438(p=0.069)$ だっ た。

\section{2. 外食チェーン店の公開情報を用いた調査}

1 ）対象の外食チェーン店の特徵

各外食チェーン店のホームページを調べた結果, 米飯 単品のエネルギー量の記載があった外食チェーン店は, ファミレスが 13 件, ランチ・定食が 1 件, 牛井・井もの が 5 件, ラーメン・餃子が 2 件, しゃぶしゃぶが 0 件, 
居酒屋／やきとりが 0 件，天ぷらが 1 件，焼肉が 1 件, とんかつが 0 件で, 天ぷらの 1 件は牛井・井ものにも含 まれていたため, 計 22 件だった。22件の外食チェーン店 の店舗数を合計すると, 2018年11月 8 日時点で 11,765 店 だった。日本標準産業分類で分類すると食堂, レストラ ンが 11 件, 日本料理店が 5 件, 焼肉店が 1 件, 中華料理 店が 2 件, ラーメン店が 1 件, その他の専門料理店が 2 件だった。米飯量の記載があった外食チェーン店は 0 件 だった。米飯単品のエネルギー量の記載がない外食 チェーン店（計73件）は, 主食がパンやパス夕などで米 飯を提供していない店（9件), チャーハンや井などの料 理された米飯しか提供していない店 (11件), セットや定 食にはあるが単品では提供しておらず米飯だけのエネル ギー量が不明の店 (13件), 米飯を単品で提供しているが エネルギー量の記載がない店 (33件), ホームページにメ ニューがない店 (4 件), バイキング形式などで食べ放題 の店（ 3 件）だった。

2 ) 外食千ェーン店の米飯量とエネルギー量

外食チェーン店の米飯量, 米飯に用いている食器, 店 の種類を表 2 に示した。外食チェーン店の普通サイズの米 飯量の最小值は $180 \mathrm{~g}$, 最大值は $250 \mathrm{~g}$ で, 中央值は 199 (181，228）g で，エネルギー量の中央值は335（305, 383）kcal だった。食堂, レストランは米飯量が少なく, 日本料理店は米飯量が多い傾向がみられた。米飯量の小 さいサイズがある外食チェーン店は 14 件で，大きいサイ ズがある外食チェーン店は 12 件だった。小さいサイズの 米飯量の中央值は138（120，150）g でエネルギー量の中 央值は232（202, 252） kcal, 大きいサイズの米飯量の中 央值は309（296，323）g でエネルギー量の中央值は520 (497，542）kcal だった。さらに特盛サイズがある外食 チェーン店は 1 件で, 米飯量は $430 \mathrm{~g}$, エネルギー量は $722 \mathrm{kcal}$ だった。前述の首都圈の飲食店における実測調 查と同様に, 米飯量の $20 \mathrm{~g}$ ごとの度数分布を図 3 に示し た。米飯量が $180 \mathrm{~g}$ 未満，または $260 \mathrm{~g}$ 以上の店はな く, $180 \mathrm{~g}$ 以上 $200 \mathrm{~g}$ 未満が11件で最も多かった。
3 ) 米飯に用いている食器と米飯量との関連

米飯に用いている食器は, 茶碗が 11 件, 平血が 5 件 で，ホームページからは不明が 6 件だった。平皿を用い ている 5 件は，ホームページ上で自身を「中華レストラ ン」や「Cafe レストラン」と称している中華系や洋風な 料理をメインとするファミリーレストランだった。茶碗 で提供している店舗の米飯量の中央值は220（192，230） $\mathrm{g}$ ，平血で提供している店舗は190（180，196）g だった。

表 2 外食チェーン店の米飯量, 食器, 店の種類

\begin{tabular}{|c|c|c|c|c|c|}
\hline & \multicolumn{3}{|c|}{ 米飯量 $(g)^{\dagger}$} & \multirow{2}{*}{ 食器 } & \multirow{2}{*}{ 店の種類 ${ }^{*}$} \\
\hline & 普通 & 小 & 大 & & \\
\hline 1 & 180 & 90 & 270 & 平皿. & その他の専門料理店 \\
\hline 2 & 180 & 100 & 300 & 茶碗 & 食堂, レストラン \\
\hline 3 & 180 & 120 & 280 & 平血. & 食堂, レストラン \\
\hline 4 & 180 & なし & なし & 茶碗 & 食堂, レストラン \\
\hline 5 & 180 & なし & なし & 不明 & 食堂, レストラン \\
\hline 6 & 180 & なし & なし & 不明 & 食堂, レストラン \\
\hline 7 & 185 & なし & なし & 茶碗 & 食堂, レストラン \\
\hline 8 & 190 & 138 & 296 & 平血. & 食堂, レストラン \\
\hline 9 & 196 & 不明 & 294 & 平血. & 食堂, レストラン \\
\hline 10 & 196 & なし & なし & 平血. & 食堂, レストラン \\
\hline 11 & 199 & 138 & なし & 茶碗 & 食堂, レストラン \\
\hline 12 & 200 & 130 & なし & 不明 & ラーメン店 \\
\hline 13 & 213 & 106 & 318 & 茶碗 & 中華料理店 \\
\hline 14 & 220 & 140 & 320 & 茶碗 & 中華料理店 \\
\hline 15 & 220 & 140 & 320 & 茶碗 & その他の専門料理店 \\
\hline 16 & 223 & なし & なし & 不明 & 日本料理店 \\
\hline 17 & 230 & 150 & 300 & 茶碗 & 日本料理店 \\
\hline 18 & 230 & なし & なし & 不明 & 食堂, レストラン \\
\hline 19 & 230 & なし & なし & 茶碗 & 日本料理店 \\
\hline 20 & 240 & 160 & 340 & 茶碗 & 日本料理店 \\
\hline 21 & 247 & 165 & 330 & 茶碗 & 日本料理店 \\
\hline 22 & 250 & 150 & 350 & 不明 & 焼肉店 \\
\hline
\end{tabular}

†「不明」は提供しているものの重量の記載がなかったこ と,「なし」は提供の有無の記載がなかったことを示す。 キ日本標準産業分類に抒ける飲食店の細分類に基づく。

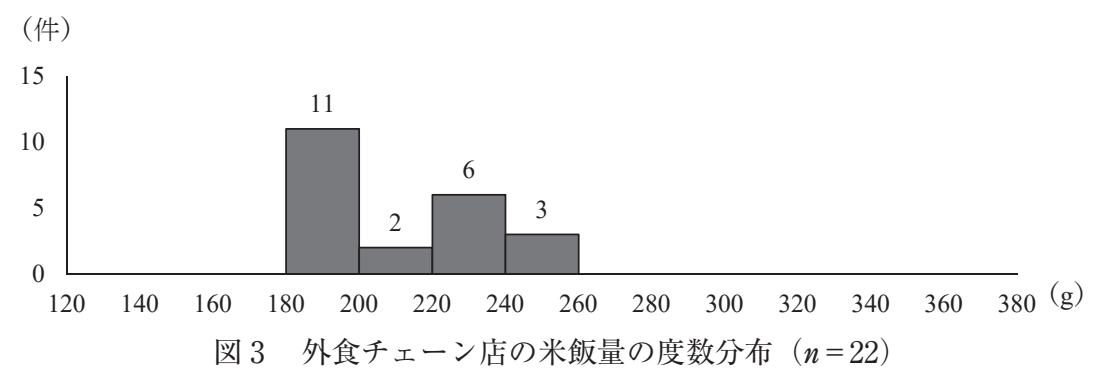

中央值 $(25,75$ パーセンタイル値) : $199(181,228) \mathrm{g}$, 最小值 : $180 \mathrm{~g}$, 最大值 : $250 \mathrm{~g}$ 


\section{N. 考察}

本研究では, 首都圈の飲食店と外食チェーン店の米飯 のポーションサイズに関して調べた。その結果, 首都圈 の飲食店の米飯量は $160 \mathrm{~g}$ 以上 $200 \mathrm{~g}$ 未満が多く, 最小 值と最大值の差が $200 \mathrm{~g}$ 程度だった。一方, 外食チェー ン店の米飯量は $180 \mathrm{~g}$ 以上 $200 \mathrm{~g}$ 未満が多く, 最小值と 最大值の差は $70 \mathrm{~g}$ だった。食器に関しても調べた結果, 首都圈の飲食店と外食チェーン店ともに，茶碗で提供し ている店が多く, 首都圈の飲食店で米飯量と茶碗の直径 に正の相関があり，茶碗が大きいほど，米飯量が多かっ た。

外食チェーン店と比べて首都圈の飲食店の方が米飯量 の中央值が小さく, 分布がばらついていた。厚生労働省 が定める健康的な食事によると, 生活習慣病の予防に取 り組みたい人の穀類由来の炭水化物の目安量は, 一般女 性や中高年男性で 40 70 g, 一般男性や身体活動量の高 い女性で 70 95 g である27)。この炭水化物量から米飯量 (水稲めし, 精白米, うるち米) を換算すると, 前者で

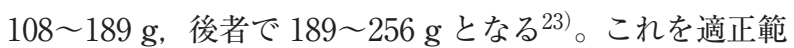
囲として本研究の結果をみると, 首都圈の飲食店の中央 值は前者の範囲内であるものの, 後者の範囲よりも多い 店が 4 店舗（18\%）あった。外食チェーン店の中央值は 後者の範囲内で, 後者の範囲を超える店はなかった。首 都圈の飲食店ではそれぞれの店で特徴を出しており, 外 食チェーン店では米飯量を一般男性の適正範囲内で設定 していることが示唆された。一方，一般女性の目安量の 範囲よりも多い店舗が多く，一般女性にとって外食の米 飯量は過剩な場合が多いことが示された。外食チェーン 店では, 小サイズの米飯を提供している店が半数以上あ り，その量は目安量の範囲内か，範囲に満たなかった。 このことから，一般女性は，外食で小サイズを選択する ことが推奨される。これに対し，大サイズを提供してい る店もあったが，その量はいずれも適正範囲以上であ り，1 食ではあるものの, 食べ過ぎに繋がる提供量で あった。

米飯の食器は, 茶碗や平皿で直径や高さが様々であっ た。ステーキ店や洋風のファミリーレストランでは, 平 皿が多く, メイン料理やコンセプトによって米飯の食器 に違いがあることが示された。食器と量の関連に関して は, 茶碗の直径が大きいほど, 米飯量が多かった。この 結果は, 食器と盛り付け量に関する先行研究16) と一致し ており, 飲食店に扔いても食器の大きさと食事の提供量 が関連していることが示唆された。外食チェーン店につ いては, ホームページから食器に関する詳細な情報が得
られず，食器と量の関連を分析することができなかった ので, 今後の課題とする。

本研究の限界点は 3 つある。1つ目は対象とした首都 圈の飲食店が各方面からの紹介により集められ，食事の 重量測定等の調查に協力してくださった店舗であるた め, 一般化が難しい点である。より一般化可能性を高め るためには, 各地域の飲食店の価格帯やジャンルを考慮 した上で対象店舗を増やす必要がある。2つ目は，実測 調查において， 1 店舗につき， 1 食を 1 回のみしか測定 していない点である。測定した定食が他の定食と比べて 代表値として適切であったかは調べておらず，測定した 重量は盛り付けした店員の個人内及び店員間で誤差が あったり，測定を考虑して少なくしたり，多くしたりし ている可能性がある。3つ目は外食チェーン店のデー夕 はホームページから収集したため, 実際に提供している 量とは誤差が生じる可能性がある点である。今後はこれ らの限界点を踏まえた上で, より一般化可能性を高め, 食環境の整備に向けた研究を推進する必要がある。

\section{V. 結 論}

本研究では, 飲食店における米飯量のポーションサイ ズについて調べるために，首都圈の飲食店において実測 調査を行い, 外食チェーン店の公開情報を抽出した。そ の結果, 首都圈の飲食店の米飯量は $160 \mathrm{~g}$ 以上 $200 \mathrm{~g}$ 未 満が多く，店ごとのばらつきが大きく，適正範囲を超え る量を提供している店もあった。外食チェーン店では $180 \mathrm{~g}$ 以上 $200 \mathrm{~g}$ 未満が多く, 中央值は首都圈の飲食店 よりも高いが，適正範囲を超える量を提供している店は なかった。米飯は茶碗で提供している店が多く, 首都圈 の飲食店では，茶碗の直径が大きいほど，提供量が多 かった。

\section{謝 辞}

本研究は JSPS 科研費18K02219の助成を受けたもので す。本研究の調査にご協力いただきました飲食店の責任 者の皆様に深く御礼申し上げます。

\section{利益相反}

利益相反に該当する事項はない。

\section{文献}

1）厚生労働省：健康日本21（第二次）, 国民の健康の増進 の総合的な推進を図るための基本的な方針, https:// www.mhlw.go.jp/bunya/kenkou/dl/kenkounippon21_01. 
pdf（2019年 7 月 2 日）

2）今田純雄 : 日本における食環境の変化と食行動, 広島 修大論集人文編，45,1-16（2004）

3）厚生労働省: 平成 27 年国民健康 - 栄養調査報告, https://www.mhlw.go.jp/bunya/kenkou/eiyou/dl/h27houkoku.pdf (2019年 7 月 2 日)

4）「健康な食事・食環境」推進事業：「健康な食事・食環 境」認証制度とは?, http://smartmeal.jp/ninshoseido. html（2019年 7 月 2 日)

5) Johnson, L.J., Raab, C., Champaner, E., et al.: Chefs' perception of the importance of nutrition in menu planning, Pak. J. Nutr., 1, 85-88 (2002)

6) Steenhuis, I., Poelman, M.: Portion size: Latest developments and interventions, Curr. Obes. Rep., 6, 10-17 (2017)

7) Young, L.R., Nestle, M.: The contribution of expanding portion sizes to the US obesity epidemic, Am.J. Public Health, 92, 246-249 (2002)

8）王雲飛, 小泉聖一, 小林信一：中国における飲食店由 来食品残さ処理・利用の現状と方向, 農業経営研究, $\mathbf{4 7}$, 173-178（2009）

9）文部科学省：食に関する指導の手引一第二次改訂 版一, 第 1 章学校に扔ける食育の推進の必要性, 学年段 階別に整理した資質・能力 (例), http://www.mext. go.jp/component/a_menu/education/detail/__icsFiles/ afieldfile/2019/04/19/1293002_4_1.pdf（2019年 7 月 2 日）

10）農林水産省：平成29年度食品産業リサイクル状況等調 査委託事業（食品関連事業者に扔ける食品廃棄物等の可 食部・不可食部の量の把握等調査）報告書, http://www. maff.go.jp/j/shokusan/recycle/syoku_loss/attach/ pdf/161227_8-56.pdf（2019年 7 月 2 日）

11）環境省：平成29年度食品廃棄物等の発生抑制及び再生 利用の促進の取組に係る実態調查報告書, http://www. env.go.jp/recycle/houkokusyo_H29.pdf（2019年 7 月 2 日）

12) United Nations: The sustainable development agenda, https://www.un.org/sustainabledevelopment/ development-agenda/ (2019年 7 月 2 日)

13) Vermote, M., Versele, V., Stok, M., et al.: The effect of a portion size intervention on French fries consumption, plate waste, satiety and compensatory caloric intake: an on-campus restaurant experiment, Nutr.J., 17, 43 (2018)

14）瀬戸美江, 山田正子, 澤田崇子, 他：飯の適正量攝取 に関与する摂取行動調查, 日本調理科学会誌, 44, 337342 (2011)

15) Van Ittersum, K., Wansink, B.: Plate size and color suggestibility: the Delboeuf Illusion's bias on serving and eating behavior, J. Consum. Res., 39, 215-228 (2012)

16) Wansink, B., van Ittersum, K., Painter. J.E.: Ice cream illusions bowls, spoons, and self-served portion sizes, $A m$. J. Prev. Med., 31, 240-243 (2006)

17) Robinson, E., Nolan, S., Tudur-Smith, C., et al.: Will smaller plates lead to smaller waists? A systematic review and meta-analysis of the effect that experimental manipulation of dishware size has on energy consumption, Obes. Rev., 15, 812-821 (2014)

18) Peng, M.: How does plate size affect estimated satiation and intake for individuals in normal-weight and overweight groups?, Obes. Sci. Pract., 3, 282-288 (2017)

19) Peng, M., Adam, S., Hautus, M.J., et al.: See food diet? Cultural differences in estimating fullness and intake as a function of plate size, Appetite, 117, 197-202 (2017)

20) Shimpo, M., Akamatsu, R.: The effects of bowl size and portion size on food intake and fullness ratings in a sample of Japanese men, Public Health Nutr., 21, 3216-3222 (2018)

21）厚生労働省：平成29年国民健康 - 栄養調査, 第 1 部栄 養素等摂取状況調查の結果 第 9 表 食品群別栄養素等 摂取量一食品群, 栄養素別, 摂取量一総数, 20歳以上, https://www.mhlw.go.jp/content/000451759.pdf（2019年 7 月 2 日)

22）吉村幸雄：エクセル栄養君 ver. 8（2016）建帛社，東 京

23）文部科学省：日本食品標準成分表2015年版（七訂） （2015）全国官報販売協同組合，東京

24）松本仲子：調理のためのベーシックデータ第 4 版 （2012）女子栄養大学出版部, 東京

25）総務省：日本標準産業分類（平成 25 年10月改定）大分 類 M 宿泊業, 飲食サービス業, http://www.soumu.go.jp/ main_content/000290732.pdf（2019年 7 月 2 日）

26）株式会社デジタルアドバンテージ：チェーン一覧, https://www.d-advantage.jp/ja/gis/quote\#food/famires （2018年11月 8 日）

27）厚生労働省：生活習慣予防その他の健康増進を目的と して提供する食事について（目安）, https://www.mhlw. go.jp/file/04-Houdouhappyou-10904750-KenkoukyokuGantaisakukenkouzoushinka/0000096859.pdf（2019年 7 月 2 日）

(受付：2019年 1 月22日，受理：2019年 6 月28日) 


\title{
Portion Sizes of Rice and Dishes at Restaurants: A Measurement Survey of Restaurants in the Tokyo, Japan, Metropolitan Area and an Analysis Using Public Information on Chain Restaurants
}

\author{
Misa Shimpo*1, Rie Akamatsu*2, Mika Saiki*3 and Kahori Fujisaki*3 \\ ${ }^{* 1}$ Department of Food and Health Sciences, Faculty of Health and Human Development, The University of Nagano \\ ${ }^{* 2}$ Natural Science Division, Faculty of Core Research, Ochanomizu University \\ ${ }^{* 3}$ Graduate School of Humanities and Sciences, Ochanomizu University
}

\begin{abstract}
Objective: The aim of this study was to investigate portion sizes of rice at restaurants.

Methods: We targeted 22 local restaurants in the Tokyo, Japan, metropolitan area (Tokyo, Kanagawa, and Saitama) and 22 chain restaurants. We measured the amount of rice and every dish in set meals and diameters of dishes of rice and calculated the nutritional value of meals at the local restaurants. For the chain restaurants, we collected data on the amount, energy, and dishes of rice using their homepages.

Results: The minimum, maximum, and median ( $25^{\text {th }}$ and $75^{\text {th }}$ percentiles) amounts of rice were $142 \mathrm{~g}, 341$

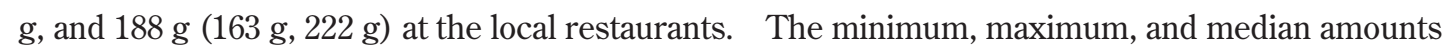
of rice were $180 \mathrm{~g}, 250 \mathrm{~g}$, and $199 \mathrm{~g}(181 \mathrm{~g}, 228 \mathrm{~g})$ at the chain restaurants. More rice bowls than rice plates were used at the restaurants. The diameter of rice bowls positively correlated with the amount of rice served at the local restaurants $(\rho=0.625, p=0.006)$.

Conclusions: The amount of rice at most local restaurants was over $160 \mathrm{~g}$ and under $200 \mathrm{~g}$. The amount of rice at most chain restaurants was over $180 \mathrm{~g}$ and under $200 \mathrm{~g}$. The median amount of rice at local restaurants was smaller than that of the chain restaurants. The amount of rice at local restaurants varied widely and was sometimes outside of proper range. Most restaurants used rice bowls, and the bigger the rice bowls, the more amount of rice served.
\end{abstract}

Jpn. J. Nutr. Diet., 77 (4) 105 112 (2019)

Key words: restaurants, amount of rice, portion size, dish 